\title{
PENGARUH TEGANGAN DC TERHADAP KECEPATAN LINEAR SEL DARAH MANUSIA
}

\author{
Nuri $^{\left.1 \mathrm{a}, 2 \mathrm{a}^{*}\right)}$, Masturi, ${ }^{1 . \mathrm{b})}$, Ian Yulianti ${ }^{1 . \mathrm{c})}$, Eny Wahyungisih ${ }^{2 . \mathrm{b})}$, Ratna sari, ${ }^{2 . \mathrm{c})}$,Endang sawitri ${ }^{2 . \mathrm{d})}$ \\ 1) Prodi Pendidikan Fisik PPS UNNES, Gedung A Kampus Program Pasca Sarjana Unnes, \\ Bendan Ngisor Semarang 50233 \\ 2) SMK Tunas Harapan Pati, Jl. Raya Pati Trangkil km 4 Pati. \\ ${ }^{*}$ Email : nuri.indramayu@gmail.com
}

\begin{abstract}
ABSTRAK
Sel darah manusia merupakan kumpulan partikel yang bermuatan listrik, jika sel ini berada dalam medan listrik akan berinteraksi sesuai dengan arah gaya luar yang memprngaruhinya. Sel darah sebagai muatan uji akan bergerk sesuai jenis muatan dan pengaruh kuat medan listrik luar yang mengeninya, semakin dekat jarak muatan uji dengan elektroda maka makin besar pengaruhnya. Dalam penelitian ini sel darah sebagai muatan uji berada pada jarak $2 \mathrm{~cm}$ daintara dua elektoda positif dan negatif. Seumber kuat medan listrik luar berasal dari elaktroda positif dan negatif. Sebagai variabel bebeas menggunakan perubahan tegangan DC dalam volt dan variable terikat adalah kecepatan sel dalam (pixel/s). Hasil percobaan didapatkan bahwa pada saat belum diberi tegangan sel darah dalam keadaan diam, pada saat nilai tegangan diberikan pada rentang $4 \mathrm{~V}-12 \mathrm{~V}$ sel darah bergerak pada rentang kecepatan $75 \mathrm{pixel} / \mathrm{s}$ hingga 600pixel/s dengan arah menuju elektroda positip. Sehingga dapat disimpulkan bahwa perubahan tegngan berpengaruh positif pada kecepatan sel darah manusia, kecepetan sel menuju elektroda positip membuktikan bahwa sel darah manusia tersebut bermuatan negatif.
\end{abstract}

Kata kinci : Tegangan DC, Sel biologi, Home scanning, Kecepatan linear, Elektroda, dan Sel darah

\section{Pendahuluan}

Disadari atau tidak bahwa tubuh kita terdiri atas sel darah yang bermuatan listrik yang dipengaruhi oleh medan listrik disekitarnya, dalam eksperimen ini medan listrik dipancarkan oleh elektroda positip. dalam kajian ini dibatasi pada ruang lingkup sejauhmana tegangan listrik mempengaruhi kelajuan dan arah sel darah jika sel didekatkan pada dua elektroda positip dan negatif.

\section{Metode Penelitian}

Penelitian dilakukan dengan cara Scaning Mikroskopis. Dengan menggunakan bantuan microscop perbesaran 1000kali dengan lensa okuler terdapat camera digital yang terhubung kabel USB pada laptop tampilan diatur sedemikin hingga bayangan tampak jelas dan tapilan layar berukuran $800 \times 600$ pixel.

Perhitungan kecepatan adalah hasil bagi jarak dan waktu tempuh. Jarak tempuh sel pada layar dengan satuan pixel, dan pewaktunya adalah durasi tayang pada video sel. Pada layar ditampilkan durasi waktu selama pergerakan sel darah.
Arah pergerakan sel darah mengidikasikan jenis muatan

Sumber masukan adalah generator DC, dengan bantuan ptensio sebagai pembagi tegangan agar nilai tegangan dapat divariasi seperti yang kita inginkan.

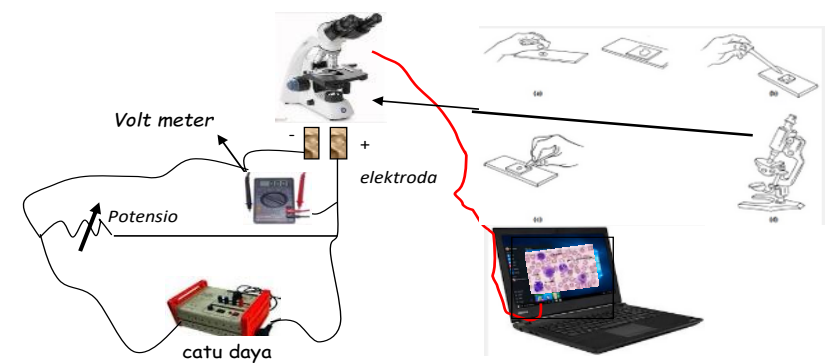

Gambar 1. Sekema percobaan

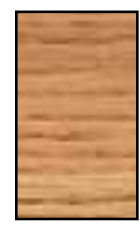

(-)

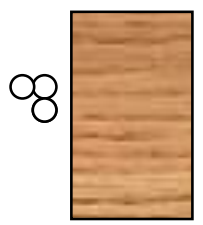

$(+$

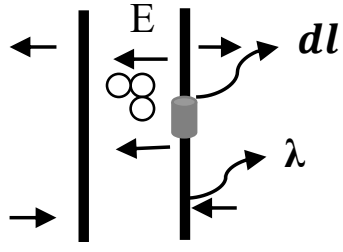

$(-) \quad(+$
Gambar 2. Ilustrasi sel darah diantara elektroda 


\section{Hasil dan Pembahasan}

Hasil penelitian :

Tabel 1. Ttabel Pengematan.

Tabel Data Hubungan Kecepatan Sel Terhadap Perubahan Tegangan DC

Jarak antara keping $2 \mathrm{~cm}$

\begin{tabular}{|c|c|c|c|c|c|c|}
\hline \multirow{2}{*}{ NO } & TEGANGAN & JARAK & WAKTU & KECEPATAN & ARAH & KET \\
\cline { 2 - 7 } & VOLT & (PIXEL) & (SEKON) & (PIXEL/S) & & \\
\hline $\mathbf{1}$ & $\mathbf{0}$ & $\mathbf{0}$ & $\mathbf{0}$ & $\mathbf{0}$ & $\mathbf{0}$ & $\mathbf{0}$ \\
\hline 2 & 2 & -200 & 7 & -28.57 & kiri & menuju kutub negatif \\
\hline 3 & 4 & 600 & 8 & 75.00 & kanan & menuju kutub positif \\
\hline $\mathbf{4}$ & 6 & 400 & 2 & 200.00 & kanan & menuju kutub positif \\
\hline 5 & 8 & 600 & 2 & 300.00 & kanan & menuju kutub positif \\
\hline 6 & 10 & 620 & 2 & 310.00 & kanan & menuju kutub positif \\
\hline $\mathbf{7}$ & 12 & 600 & 1 & 600.00 & kanan & menuju kutub positif \\
\hline
\end{tabular}

Tabel 2. Grafik hubungan Teganagn DC Terhadap Kecepatan lienar sel

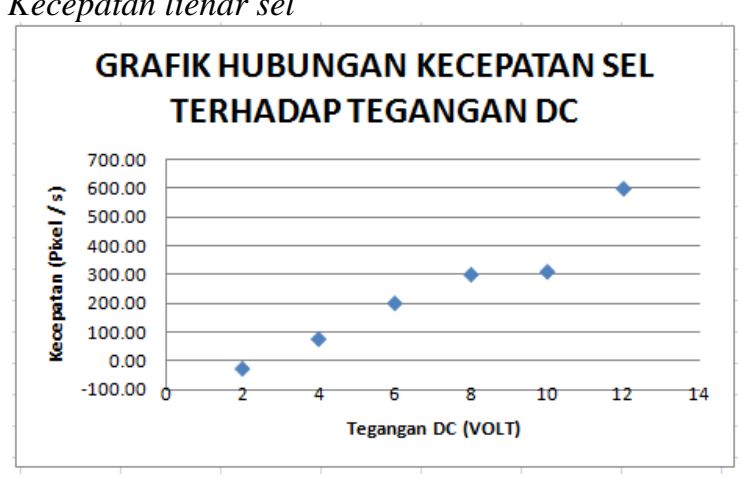

Hasil percobaan didapatkan grafik sumbu y sebagai variabel terikat yaitu kecepatan linear sel dalam (pixel/s), dan sumbu $\mathrm{x}$ sebagai variabel bebeas yaitu tegangan listrik DC dalam (volt).

Al hasil adalah perubahan tegangan listrik berpengaruh secara linier terhadap perubahan kecepatan gerak sel darah dengan gerak menuju kutub positif. dalam keadaan tanpa arus listrik sel darah diam, pada saat tegnagan 2 volt, sel bergerak menuju kutub negatif dengan kecepatan sel 28,57 pixel/sekon, pada tegengan 4 volt kecepatan sel $75.00 \mathrm{pixel} / \mathrm{sekon}$, menuju arah kanan mendekati elektroda positif, pada tegangan 6 volt kecepatan sel $200 \mathrm{pixel} / \mathrm{sekon}$, menuju arah kanan mendekati elektroda positif, pada tegangan 8 volt kecepatan sel $300 \mathrm{pixel} / \mathrm{sekon}$, menuju arah kanan mendekati elektroda positif, pada tegangan 10 violt kecepatan sel 310 pixel/sekon, menuju arah kanan mendekati elektroda positif, pada tegangan 12 volt kecepatan sel 600 pixel/sekon, menuju arah kanan mendekati elektroda positif.

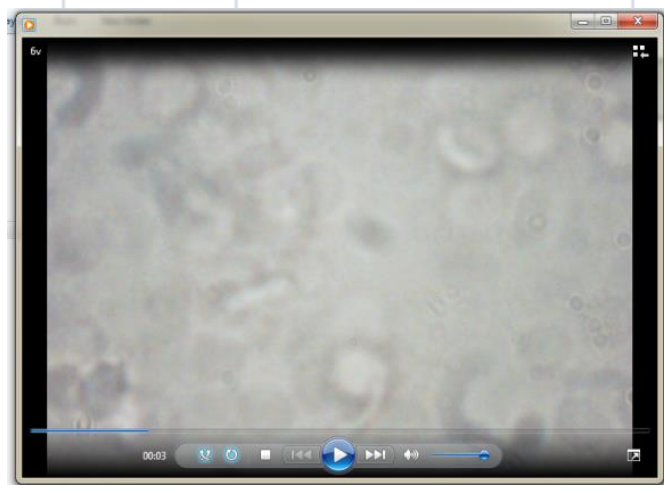

Gambar 2. Rekam gambar pada layar laptop

\section{Simpulan}

Dapat disimpulkan bahwa :

1. Tegangan mempengaruhi kecepatan linear sel darah.

2. Sel darah menuju elektroda positif maka disimpulkan sel darah memiliki muatan negetif.

\section{Ucapan Terimakasih}

Penelitian ini terwujud berkat ridho Alloh SWT, serta dukungan keluarga, maka dari itu ucapan terimakasih pada istri tercinta dan anak-anakku, tidak lupa penulis ucapkan terimakasih kepada kepala sekolah Smk Tunas Harapan Pati yang telah mengijinkan penelitian ini, terimakasih kepada ketua kompetensi keahlian kimia analis yang telah meminjamkan alat sehingga penelitian dapat berjalan, terimakasih pada siswaku Moh. Khoirunajib yang telah membantu dalam teknis pelaksanaan serta tak lupa rekan-rekan mahasiswa PPS Unnes pendidikan fisika 2015. 


\section{Daftar Acuan}

[1] Ws Teerapt and Ph Phadungsak. Flow and heat transfer in biological tissue due to electromagnetic near-field explosure effects. Thailand (2015).

[2] Wiyanto. Elektromagnetika, yogyakarta, Graha ilmu (2008), p. 25-114

[3] Griffiths, D.J Introduction to Electrodynamics. Second Edition. New delhi : prentic-Hall of India Private Limited (1989), p. 44-281

[5] Rizka Ismatu, elektrorotasi sel telur lele semarang (2007)

[6] https://alkafyuone.wordpress.com dikutip 4 april 2016

[7] Evy Siscawati dalam Faktallmiah:2012 dikutip 5 april 2016 
